\title{
Pulmonary Agenesis
}

National Cancer Institute

\section{Source}

National Cancer Institute. Pulmonary Agenesis. NCI Thesaurus. Code C99028.

An uncommon cong enital abnormality characterized by either lethal complete absence of the lungs or varying degrees of underdevelopment of the lung parenchyma. It may be associated with other cong enital abnormalities. 